\title{
TRADITIONAL GAME TO DEVELOP CHARACTER VALUES IN NONFORMAL EDUCATIONAL INSTITUTION
}

\author{
Ari Putra ${ }^{1}$, Viena Rusmiati Hasanah ${ }^{2}$ \\ ${ }^{1}$ Mr, Universitas Pendidikan Indonesia, Indonesia, arie_poetra67@yahoo.co.id \\ 2 Dr. Universitas Pendidikan Indonesia, Indonesia, viena@upi.edu
}

\begin{abstract}
This research departed from the tradition of Indonesian culture that has been done by the communities because of the current globalization. Kaulinan Barudak Lembur is a traditional game performed by children in the countryside. Nowadays, children are starting to love the digital game compared with traditional games. The Kaulinan Barudak Lembur has many values which is important to be internalized to children because good values should be habits from an early age. One of many ways can be developed through the introduction of traditional games. This study aims to describe the type and characteristics of traditional games in Eco Bambu Cultural, Art, and Sport Center and to describe the character values contained in traditional game Kaulinan Barudak Lembur for children learnig in the Eco Bambu Cipaku Cultural, Art, and Sport Center, West Java. This research used qualitative method by using ethno pedagogical approach. Data in this research were collected by observation, documentation, interview, and recording. Technics of data analysis were collecting data, selecting data, interpreting data and taking conclusion. The results of this study were cultural literacy through the Kaulinan Barudak Lembur is able to develop the values of character education, such as religious value, cooperation value, responsible value, honesty value, caring value, selfconfidence value and curiosity value. It can be concluded that the Kaulinan Barudak Lembur is a traditional game that have to be preserved because it contains various values of character education that can contribute in creating good character for children from an early age. Furthermore, the implications of this research are to make children have good character from early age and to make tutors know that so many values of character education in that traditional game so they can implement that game to internalize good values for children.
\end{abstract}

Keywords: Traditional Games, Character Values, Nonformal Educational Institution

\section{INTRODUCTION}

Indonesia is a country which has diversity culture. It began to erode over time by the flow of globalization it can be seen from lack of traditional cultural values and habits by the society. Three things that must be executed simultaneously in the process of improving the quality of education are: affective, cognitive, and psych motoric (Tim Kreatif LKM UNJ, 2011). The role of education is as a bridge to educate individual or social groups in order to be able to preserve the culture. As a cultured nation, individual within the 
community group should uphold the values of religion, noble values, wisdom and character (Perpres, 87: 2017) so that the nation's culture remains inherent in Indonesian society.

The current character crisis strucks the Indonesian nation, for example many mass media that preach that many teenagers who do activities which are not appropriate with social norms, such as: fights among students, free sex, drugs, and lack of respect to older people. This is a big challenge that we must face today. At least there are three things that make person has good character. They are knowing each other, having a sense of care, and trust for himself and the group (Juma, Abdu, p.139: 2012). Character education is one of the ways used to direct a person in living which accordance with the ethics and morals prevailing in a society (Istiningsih, p.35: 2016). The goal is to create a capable human being in the face of the dynamics of life in the future, and to repair the potential of all educational actors. Character education aims is to form a good human where the good criterion in society is able to implement certain aspects of social values that are influenced by the people's character in group (Fathurrohman, Puput, p.15: 2013). The success of the character education program is not being separated from the synergy between the community, schools and families (Anggriani, Purwanti, et all. p.29: 2016). For that, in improving the character education development needed the help parties either through the role of education and environment.

The traditional games of Indonesia are the concept of a cultural heritage tradition passed down by the ancestors to every generation and preserved according to local wisdom. Traditional games can be used in strengthening the character of each player. Traditional games give values of character that can shape the individual attitude to be better in the future.

The Kaulinan Barudak Lembur is a term taken in Sundanese language that means the game for children. The Kaulinan Barudak Lembur is simple and very easy to be made. The Kaulinan Barudak Lembur is divided into two types. They are the Kaulinan Barudak Lembur using the song and the Kaulinan Barudak Lembur using the movement. Many kinds of the Kaulinan Barudak Lembur in the society namely: Egrang, Gobak Sodor, Congklak, Cingciripit, and Bebedilan, etc. Based on the observation done in Eco Bambu Cultural, Art, Sport Center, people around the non-formal education institution are interest with the Kaulinan Barudak Lembur very much. That's why the Kaulinan Barudak Lembur is included into learning curriculum in Bandung, namely Bandung Masagi. Not only Bandung people enjoying it, but also participants from outside Bandung such as Jakarta, Cikarang, Bekasi, Tangerang and from another island. They visit to Eco Bambu to follow The Kaulinan Barudak Lembur game. Tutors provide guidance to each participant who follow this activity. Generally, the Kaulinan Barudak Lembur was often held by the society. Unfortunately, today it seemed to disappear and rarely held in the community due to various factors such as: the lack of land to play it, and gadget is more attractive than traditional games, etc. For that reason, the existence of the Kaulinan Barudak Lembur is promoted by the Eco Bambu Cipaku Cultural, Art, and Sport Center. In this context, this game has a contribution in non-formal education, so this study need to examine the contained in the process of activity such as recreation. Recreation is an activity for all of people. It is a learning solution as media for non-formal education. This activity is a study tour which has aim to create a joyful learning, so it will be easier to understand as meaningful. The concept of this activity is divided into two types of short and full time implementation (Suprijanto, p.132: 2007).

Character education is a concept of moral education. It is conducted in the learning program to develop the habit of attitude which is acceptable in the society. Character education developed is divided into several character values such as cheerfulness, joyfulness, citizenship kindness, cleanliness loyalty, compassion patience, cooperation perseverance, courage punctuality, courtesy respect, creativity, respect for the environment, dependability responsibility, diligence school pride, fairness self-control, generosity, sportsmanship, helpfulness, tolerance, honesty (Elmeel, L Sharron, xvi: 2002). It shows that the character education has many benefits to be implemented in everyday life.

The character education is reinforced by the rule of president of Indonesia No. 87 in 2017 on strengthening character education, instruction of character education to begin to be organized within each type of formal, non-formal and informal education services. The development foundation of the character education in the three areas: social, emotional and personal development. The concern of character education learners is expected to apply some values that can be implemented in everyday life such as: to value themselves, respect others, be responsible, cooperate with other individuals, solve problems, and be honest and trustworthy (Tannir, Abir, et al., p.47: 2013). Base on the explanation above, this research will describe the type and characteristics of traditional games which are conducted in Eco Bambu Cultural, Art, and Sport Center and to give descriptions about many character values which are contained and found in traditional game Kaulinan Barudak Lembur in the Eco Bambu Cipaku Cultural, Art, and Sport Center, West Java. Therefore, on this paper, the writers are really interested to do the research entitle "Traditional Game to Develop Character Values in Nonformal Educational Institution". 


\section{MATERIALS AND METHODS}

This study used a qualitative method with thinking inductively in ethno-pedagogic approach (Musfiqon, 70: 2012). The ethno-pedagogic approach is an educational practice derived from a study of cultural values in pedagogic values (Albaiti, p.14: 2015). Ethno pedagogic comes from ethnography approach which has characters as holistic research, integrative, thick description. Technique of data collection is done by using participation-observation, open and deeply interview. The observation on this research was done for two months. On that time, Researchers also did documentation to get more comprehensive data needed. Then, beside doing those two technique, researcher also did interview to some respondents who are the facilitators in that Nonformal Educational Institution. By doing many ways, the researchers will get the valid data about the types, characteristics, and character values in the traditional game. Therefore, in this research, researcher try to show completely about characteristic of traditional game and the values of character education in that traditional game.

\section{RESULTS AND DISCUSSION}

\subsection{Types and Characteristics Kaulinan Barudak Lembur in Eco Bambu Cipaku}

Base on the observation which was conducted in this research, researchers concluded that the type and characteristic of Kaulinan BArudak Lembur are consists of Egrang, Gobak Sodor, Congklak, Cingciripit, and Bebedilan.

\subsubsection{Egrang}

Base on the observation which was done in Eco Bambu Cipaku, Egrang is a walk with bamboo rides which has varying heigt according to the participant's height's. In this study egrang has $180 \mathrm{~cm}$ in height. Egrang has a footing use to sustain the players body. It is easy to find the material of egrang, because the game is mate by using bamboo or wooden media that has become the bottom triangle, then one of the triangle is lengthened to be use as handrails. Footrests are made without nails, but tied with a rubber tire-based binder. The egrang are not limited to the availability of the egrang, everyone gets a pair of the egrang to play.

Reserchers did observation that this game can only be done by one person only. Person who do not have self-confidence often has difficulty to move the bamboo that sustains his body. Participants playing are not limited by the availability of the egrang. Everyone gets the appair of the egrang to play. To play this game doesn't need a lot of rules. The game just need strength belief that we can play it. The steps to play the game are 1) prepare a pair of the egrang and ready to use it, 2) tutors give a guidance the winner is the participant firstly returning to starting point.

\subsubsection{Gobak Sodor}

Accoirding to observation and interview to some respondents in Eco Bambu, researchers got the information that Gobak sodor is a game played by group. The group is consisted by 3-6 persons. The gobak sodor (galah asin) is played in open field with 6 rectangle divided into two areas. They are two groups playing it. The position of first group is as a guard team. The member of the first group guards on each side of the area. The second group is an attacker. Their task is to enter area which is guarded by the first group. The winner of this game is a team having more or complete member. The guards just can catch the rival through the outline of area. If a guard catch the rival by entering the area, then the caught rival will be uncounted catching. The position of the guard will be changed if all of members passing the area without caught. To play this game doesn't need a song. The game need a teamwork. The main key to win the game is to be survived that the rival can't pass through dividing the line of area. The steps to play this game are

1. Making 6 rectangle as the area

2. Splitting the participants into two teams: attacker and guard

3. Enjoying the game with the rule

In playing the gobak sodor, every player of each team must move along the line. The foot of the member must be on the line. Each team strikes from the starting line and passes all of transverse lines guarded by opponent. If there are some player who passed and returned successfully to the beginning of the line the attacker declired victorious. If the rival touchs one member of other team then the guard team declires the victorius. Two team is switching and so on.

\subsubsection{Congklak}

Congklak is a game using wood media that has 14 small holes and two medium holes located on the edge. 
The holes of the two game participants to determine the winner of the game. The hole is filled by seven small stones, seeds or shells. The two medium holes have the function as saving to determine the winner from to participants in the game. Base on the observation which was done in Eco Bambu, researchers find that the way to play the congklak is each player will determine their area of seven small holes and a hole a saving. Player A moves a stones or seeds by inserting it into all the holes. In this game, player able to attack another player namely shooting the hole by taking all of the stone in the hole beside (Player B') and save the shooting result into Player A's saving hole, then continue Player B to play the game. If the last stones fell on a hole that still contains stones or seeds, then the game continues until there is no stones on the hole, and continue until a participant's areas of seven holes is empty. The winner is player which has more stones or seeds then another player.

\subsubsection{Cingciripit}

Cingciripit game is the kaulinan kakawihan or game by using song. Base on the observation and interview which were done in Eco Bambu, researchers get the information that The Cingciripit classified as a simple game that uses the media of the hands and fingers which is played in a rollicking situation, so the game will be more fun while it played by many people. The players re directed to make a circle with opening their right palm and left finger taped on the palm of the open friend's right hand. The song singing from very slow, medium, and fast melodies. There is a game guider to direct this game. Researchers heard that The songs are sung as follows:

\section{Cing ciripit}

Tulang bajing kacapit

Kacapit ku bulu pare

\section{Bulu paré seuseukeutna}

Jol, Pa dalang mawa wayang, Jekjeknong.

Participants who are caught fingers will be grouped first until several people collected and given a penalty that can entertain other participants. The winner is a participant which is the finger cannot be caught by other participants.

\subsubsection{Bebedilan}

This is a kind of war game using a gun that made by wood or bamboo and rubber band to shoot bullets in the form of grain. According to the observation done by researchers, players in Bebedilan are children grouping in some teams and can attack each other in this game. Players affected by Bebedilan bullets are considered defeated and cannot continue the game. This game requires strategy and direction from the group leader in order to make your opponent lose. This game is done by stepping several times to the opponent for the grain can hit the opponent. It is not advisable to strike an opponent at close range and on vital organs.

\subsection{The Value of Character Education in Kaulinan Barudak Lembur Game}

Base on the some techniques which are conducted by researchers, there are five character values found in this research. Those values are religious, cooperation, honesty, caring, and self-confidence. Those five character values are chosen because they are highly dominant in the development of character education which is implemented in the Kaulinan Barudak Lembur game. Also, researchers got some additional information from some respondents. It actually has relevance with data gotten by researchers. $\mathrm{X}$, a facilitator in that institution, mentioned that the traditional game in Eco Bambu has many types and characteristics. It is also so useful for children. With many variations, it will make children are not bored to come and to join in playing that games". Also, Y, who is facilitator stated that the traditional games in Eco Bambu is an educational game. It is because most of those games contain many good values of education. It will help to develop morality, attitude, and great values for children so that they can implement it in their own daily life". Furthermore, Manager of Eco Bambu said that through that traditional game, the attitude of children will be better and make the happy and be enjoy during playing that game. Also, that good values will be internalized to them forever. Base on the information from the manager, children who always come to Eco Bambu have great character. It is seen from their behavoiur, attitude, and how they interact each other. Here is the following explanation as the results and discussion of this research.

This following link describes correlation between traditional games and character values developed by nonformal educational institution: 


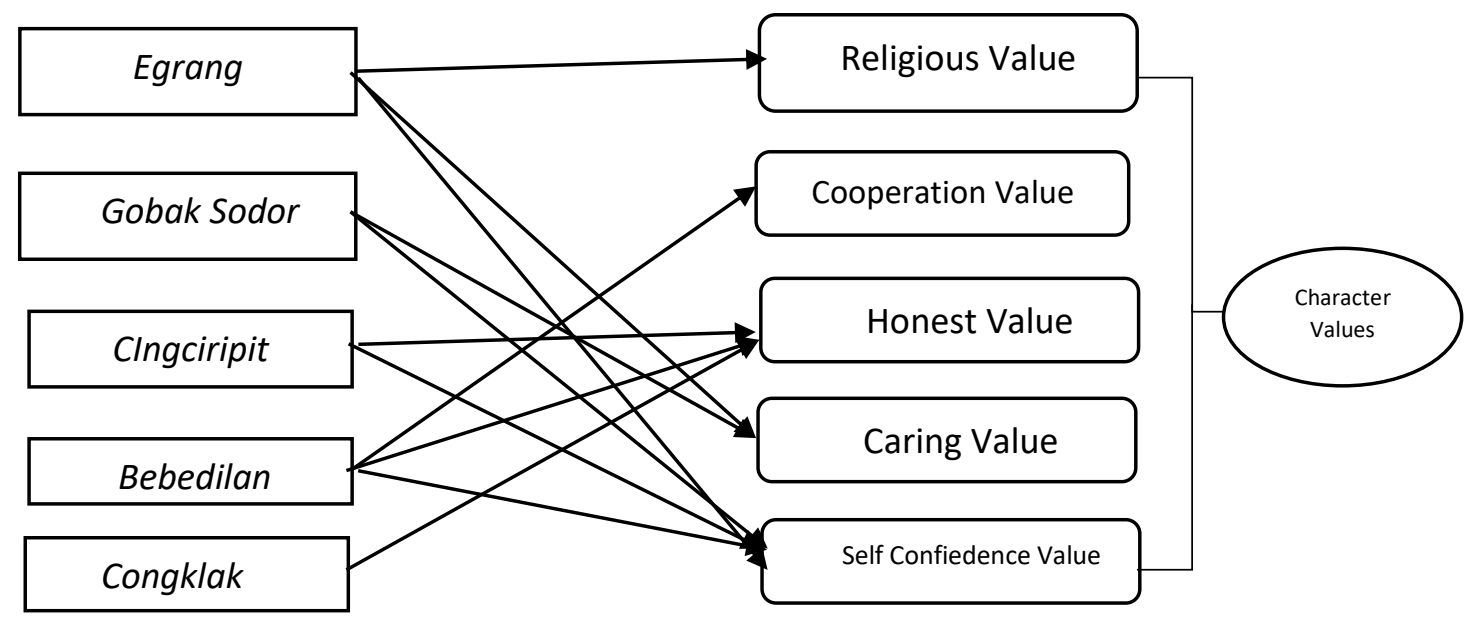

Figure 1. Correlation between The Kaulinan Barudak Lembur and Values of Character Education

\subsubsection{Religious Values}

Religious values in the Kaulinan Barudak Lembur found in Egrang game. At the time of the game the participants are directed by the companion to bow their heads while praying to God according to their religion and belief to be given ease and safety in running the game activity. Not only is it directed to pray, the spontaneous Muslim participants say the word Bismillahirrahmanirrahim (the name of Allah the Most Gracious, the Merciful). The meaning of this sentence is a form of closeness between the creator and the human being that there is absolutely no barrier between Allah SWT and the human. Submit to God to do every activity that will be followed to make the participants the Kaulinan Barudak Lembur sure able to run every activity. It can be a habit that will be implemented by everyone if the individual runs its activities. The process of surrendering oneself fully to God in carrying out every activity is a tangible form of religious character.

\subsubsection{Value of Cooperation}

In the Kaulinan Bebedilan or war games performed in the group reflect the value of very strong cooperation within each group. It needs cohesiveness for all members of the group to form a solid team. Values found in the game The Bebedilan cooperation, namely, when participants will start the game, the team gathered first to determine strategy game and the tasks for each individual included in the team. The group leader directs and provides a strategy to members to attack and win the game. Cooperation began to form in the team, which members of the previous team did not know each other and do not have the emotional closeness because when performing division of the team, a companion games do random techniques to divide groups. Compactness and cooperation directly from within themselves. They must do well cooperative in completing missions. From the observation result in this study, every member work together in rescuing other members who are difficult on the field in order to attack the opponent in this game.

\subsubsection{Honesty Value}

The honesty character value was found in three games organized by Eco Bambu cultural and sport studio, including: Congklak, Cingciripit and Bebedilan. The details of the character values found in the three games are described as follows:

1. Congklak game participants are invited to be honest at the time of playing in filling every small hole contained in the congklak box until it finally reaches the player's own savings hole. The game of congklak is carried out without the referee, the referee in the congklak game is the player who becomes the opponent. The job of the opponent is pay attention to his opponent's playing hand in inserting any grain of seed filled by the player. If there is a cheating in this game, the participants get punished or disqualified and may not continue the game.

2. The honesty value also found in Kakawihan Cing Ciripit, namely the process of self-admitted that his index finger has been caught by the palms of players and participants whose fingers are caught by the players who are next to him must be in law. There is no limit to the participants in the kakawihan cingciripit. This game demands honesty and concentration of participants in balancing two things, namely the process of singing and playing. Participants were invited sit circularly or row in line while singing the cingciripit. When the participants already caught by another participant, she/he will be 
IJAEDU- International E-Journal of Advances in Education, Vol. IV, Issue 10, April 2018

punished by go outside the group to wait for the punishment by another participant.

3. The Bebedilan game also showed the honesty value. It can be seen while the loser admitted his defeat by hands up and go outside the game area automatically, so another participant will not able to shoot him/ his again.

It can be concluded that from the three games above provide good value for each player. The honesty value can be a habit by every individual in the daily life and improve the quality of individual.

\subsubsection{Caring Value}

It can be found the caring value in the most of Kaulinan barudak Lembur, even it is not too specific. From the game, the sense of concern for the colleague participants and the environment emerged from the participants of educational recreation. At the time of the game Egrang begins game participants trying to care for his colleagues who cannot ride the Egrang by helping to hold the stalks the Egrang that will be used. Similar to the Egrang, the game of Gobak Sodor also increases the sense of concern for the team, every member who became participants in this game showed concern for each other in giving encouragement to his colleague who played in the Gobak Sodor area. Shouted "Come on, move on" into the team's concern in encouraging every member to play. In addition, quick responsiveness in helping members who fall or injury in the game also shows the attitude of concern shown by the players to colleagues or opponents. They interpret this is just a game, not a big competition. For that, the game Egrang and Gobak Sodor form a sense of concern from every player or audience of this activity.

\subsubsection{Self Confidence Value}

Self confidence in the Kaulinan Barudak Lembur was found on Egrang, Gobak Sodor, Cingciripit, and Bebedilan. Self-confidence is a process in the courage to make choices. This value shown by each participant who plays the game can believe himself to running the Egrang. The participant is able to trust another participant as steering to provide direction until the end of game.

Participants in the Gobak Sodor are invited to be able to trust himself to get to the finish line and through obstacles. Participants trust their partner who becomes steering wheel to move the box so that it can reach the finish line. Participants in the Cingciripit also believe himself to raise his hand at the right time when the song being stopped or just a hoax. In the game Bebedilan, participants have self-confidence to pull the lever from Bebedilan and shoot it right the opponents. To develop this value well, it needs repetitive activities.

\section{CONCLUSION}

Kaulinan Barudak Lembur is a game performed by rural children having many meanings and values of characters. The character education invested through traditional games can be attached to the participants who play this game until adulthood. The hope of the traditional games held in this non-formal education institution, can be complementary in the implementation of formal education. Teaching and learning activities organized by formal education will be complete if it is implemented simultaneously with non-formal education, so the synergy can be established. The expected learning process not only about input-processoutput, but also the result as an outcomes impact that can be embedded within each game participant. The result form is a character value and can be an identity that able to strengthen the character of Indonesian children so they can become a good person in the future.

\section{ACKNOWLEDGEMENT}

This research was funded and supported by Indonesia Endowment Fund for Education (LPDP). In this great chance, researchers want to say thaks to LPDP for all the helps. Also, Researchers thank to Eco Bambu Cultural and Sport Studio fo giving the access to do this research.

\section{REFERENCE LIST}

Albaiti, A. (2015). Kajian Kearifan Lokal Kelompok Budaya Dani Lembah Baliem Wamena Papua. JURNAL PENDIDIKAN NUSANTARA INDONESIA, 1(1), 14-33.

Anggraini, P., \& Kusniarti, T. (2016). The Implementation of Character Education Model Based on Empowerment Theatre for Primary School Students. Journal of Education and Practice, 7(1), 26-29. 
Anonim. (2017). Peraturan Presiden Republik Indonesia. Nomor 87 Tahun 2017. Tentang Penguatan Pendidikan Karakter. Jakarta.

Fathurrohman, Pupuh, Dkk. (2013). Pengembangan Pendidikan Karakter. Bandung: PT Refika Aditama.

Istiningsih. (2016). Character Education of the Most Developed Countries in ASEAN. Journal of Education and e-Learning Research. Vol. 3, No. 1, 32-37.

Juma Abdu Wamaungo.(2016). Mendidik Untuk Membentuk Karakter "Bagaimana Sekolah Dapat Memberikan Pendidikan tentang Sikap Hormat dan Tanggung Jawab.Bumi Aksara:Jakarta.

Tim Kreatif LKM UNJ. (2011).Restorasi Pendidikan Indonesia:" Menuju Masyarakat Terdidik Berbasis Budaya". Ar-Ruz Media. Jakarta.

Tannir, Abir et all. 2013. Effects of Character Education on the Self-Esteem Of Intellectually Able and Less Able Elementary Students in Kuwait. International Journal of Special Education. Vol 28, No: 1.

Musfiqon. (2012). Panduan Lengkap Metodologi Penelitian Pendidikan. Prestasi Pustaka: Jakarta.

McElmeel, L. Sharron. (2002). Character Education: A Book Guide for Teachers, Librarians, and Parents. Teachers Idea Press: Colorado.

Suprijanto. (2012). Pendidikan Orang Dewasa: Dari Teori Hingga Aplikasi. Bumi Aksara. 